ОСОБЛИВОСТІ САМОСВІДОМОСТІ МАТЕРІВ У ПРОЦЕСІ ПЕРЕЖИВАННЯ НИМИ ЕМОЦИЙНОГО ВИГОРАННЯ

\title{
PECULIARITIES OF MOTHERS' SELF-CONSCIOUSNESS IN THE PROCESS OF EXPERIENCING EMOTIONAL BURNING
}

у чій статті розглянуто френомен самосвідомості матерів. Зазначено, що самосвідомість матерів являє собою складне утворення, що формується поетапно та поступово, опосередковується багатьма факторами, зокрема, готовністю до материнства, віком першого материнства, рівнем особистісної зрілості, та представлене у формі синтетичного поєднання самопізнання, самоставлення та самореалізації. Розглядаючи самосвідомість матерів, увагу зосереджено на тому, що із появою дитини у жінки змінюється сприйняття власного соціального статусу, сприйняття часу та формується материнська ідентичність, позиція «Я-мати». В результаті проведеного теоретичного дослідження було виявлено, що поряд зі значною увагою до вивчення френомена самосвідомості матерів проблема особливостей самосвідомості матерів у процесі переживання ними емочійного вигорання залишається не досить розкритою. Було показано, що матерям, які переживають емоційне вигорання, властиві проблеми самопрезентації в аспектах індивідуальне Я, реляційне Я та колективне Я, а також зниження самооцінки, високий рівень самокритичності, деперсоналізація, відчуття власної неповноцінності тощо. Найбільш представленими фрормами ідентичності матері виявилися рефлексивна та соціальна. Цей результат може відображати, що оцінка особистісних якостей та прояв емоційного ставлення до себе, усвідомлення приналежності до соціальних груп виступають певними психологічними складниками в зумовленні материнської самосвідомості у процесі переживання ними емоційного вигорання.

Пілотажне дослідження дозволило встановити існування кореляційних зв'язків між показниками самоставлення та трьома фазами емоційного вигорання. При цьому стаж материнства має виражені зв'язки із особистісною відстороненістю та віком матерів. Рисою матерів, що опосередковує емоційне вигорання, є прагнення реалізувати себе не тільки у материнстві, а й в інших сорерах їхньої життєдіяльності. Одночасно з тим високий рівень вимог суспільства до жінки як матері та дихотомічність мислення, емоційна полярність і неадекватна самооцінка жінок може бути предиктором розвитку емоиійного вигорання та знаходити прояв у психосоматичних симптомах. Ключові слова: самоставлення, самосвідомість, емоційне вигорання, особистісні властивості,

стаж

материнства, ідентичність.

This article examines the phenomenon of mothers' self-awareness. It is noted that mothers' self-consciousness is a complex phenomenon that is formed gradually and step by step, mediated by many factors, including the age of first motherhood, readiness for motherhood, level of personal maturity, and presented in the form of a synthetic combination of self-knowledge, self-esteem and self-realization. Considering the self-consciousness of mothers, attention is focused on the fact that with the advent of the child, women change the perception of their own social status, perception of time and the formation of maternal identity, the position of "I-mother". As a result of the theoretical study it was found that much attention is paid to the study of the phenomenon of mothers self-awareness, and the problem of mothers self-consciousness in the process of experiencing emotional burnout remains incompletely disclosed. It has been shown that mothers who experience emotional burnout have problems with self-presentation in terms of individual self, relational self and collective self, as well as low self-esteem, high levels of self-criticism, depersonalization, feelings of inferiority and etc. The most represented identities of the mother were reflexive and social. This result may reflect that the assessment of personal qualities and the manifestation of emotional attitude to themselves, awareness of belonging to social groups are certain psychological components in determining maternal self-awareness in the process of experiencing emotional burnout.

The pilot study established the existence of correlations between self-esteem and the three phases of emotional burnout. At the same time, the length of maternity has strong connections with personal detachment and psychosomatics, as well as a connection between the age and psychosomatics of mothers. A feature that mediates the emotional burnout of modern mothers is the desire to realize themselves not only in motherhood, but in a wider range of areas. At the same time, the high level of society's demands on women as mothers and the dichotomy of thinking, emotional polarity, and inadequate self-esteem of women themselves can be a predictor of the development of emotional burnout and find manifestation in psychosomatic symptoms.

Key words: self-attitude, self-awareness, emotional burnout, personal characteristics, maternity experience, identity. імені Олеся Гончара

Постановка проблеми. Сучасний світ характеризується численними трансформаційними процесами, серед яких - зміни на рівні суспільства, сім'ї, зокрема патернів сімейних стосунків і репродуктивної поведінки жінок. Сьогодення диктує нові умови для реалізації жінки, а тому вона більше уваги приділяє розвитку кар'єри, досягнення визнання, тому створення сім'ї відстрочується, кількість дітей у родині зменшується, для жінки цінність материнства все більше посідає проміжне місце поряд із цінностями самореалізації, професійними та матеріальними цілями. Особливої уваги потребує дослідження усвідомлення людиною таких змін, адже трансформаційні зміни сьогодення позначаються і на самосві- 
домості особистості. Низкою вчених (І.С. Кон, О.М. Леонтьєв, С.Л. Рубінштейн та ін.) зазначається, що рівень розвитку особистості $\epsilon$ пропорційним до рівня розвитку їі самосвідомості $[24$, с. 5]. Таким чином, з урахуванням швидкоплинних змін у сучасному суспільстві, у сфері сім'ї та відносин актуальним $€$ дослідження самосвідомості жінок, особливостей сприйняття ними материнства та проявів материнської ідентичності. Зокрема, через підвищення рівня вимог до матерів, прагнення досягти ідеалу у материнстві особливої уваги дослідників потребує проблема самосвідомості матерів, що переживають емоційне вигорання.

Метою статті $€$ висвітлення результатів дослідження специфіки самосвідомості матерів у процесі переживання ними емоційного вигорання.

Аналіз останніх досліджень та публікацій. Вивченню психологічних аспектів самосвідомості особистості присвятили свої роботи В. Джемс, І.С. Кон, О.М. Леонтьєв, К. Роджерс, С.Л. Рубінштейн, З. Фрейд, Г. Олпорт, Е. Еріксон та ін. Самосвідомість матерів досліджували: С.О. Ангелова, Л.А. Базалева, О.Н. Рибакова, Д.О. Савенко, М.Ю. Кожина, М.М. Кулеша-Любінець, М.Ю. Чібісова, Т.І. Щербак. Материнство досліджується як самостійний феномен (Г.Г. Філіппова), вивчаються базові якості для реалізації ролі матері (А.І. Захаров, А.С. Співаковська), а також внутрішні і зовнішні детермінанти материнства (Е.І. Єсеніна, Н.Н. Васягіна, Н.А. Устинова) [6, с. 75].

Структура самосвідомості $€$ складною і включає Я-концепцію особистості, самоставлення, саморегуляцію та самопізнання. Доведено, що формування самосвідомості відбувається поетапно та опосередковано [6, с. 75]. Однією з детермінант, що опосередковує самосвідомість жінки, викликаючи психологічні та соціальні перебудови у її структурі, є народження дитини. Жінка займає позицію "Я-мати», що, крім іншого, позначається на сфері її домагань [24, с. 10; 25, с. 15]. Самосвідомість матері виступає утворенням, що синтетично поєднує три компоненти:

1. Самопізнання формується поступово, від окремих образів своєї поведінки як матері до цілісного сформованого відображення себе як матері, утвореного на основі аналізу своєї поведінки під час різних обставин та у різних ситуаціях. Накопичення образів себе в результаті призводить до формування узагальненого образу «Я-мати» [6, с. 75].

2. Самоставлення представляє оцінку жінкою того, як вона виконує материнські обов'язки і може характеризуватись конфліктом між уявленнями жінки про себе як про матір та ідеальним образом матері. 3 одного боку, самоставлення виникає в результаті самопізнання жінкою самої себе, а з іншого боку, вже сформоване самоставлення може опосередковувати напрям та індивідуальні особливості самопізнання [6].

3. Самореалізація являє собою те, яким саме чином матір організує свою взаємодію з дитиною, емоційні переживання під час взаємодії, реагування на дії та поведінку дитини, стиль цієї взаємодії та тип дитячо-батьківських відносин [6].

Процес побудови образу себе як матері залежить від представленості багатьох факторів, зокрема досвіду першого материнства, готовності до материнства, особистісної зрілості тощо. Так, за результатами досліджень М.Ю. Чібісової, молоді матері сприймають материнство як новий статус на рівні суспільства і сім'ї. У сприйнятті часу жінка акцентує увагу на теперішньому, в якому перебуває дитина як безумовна цінність [25, с. 20]. Одним із факторів, що впливає на прояв та формування самосвідомості, $€$ рівень емоційного вигорання. Зокрема, дослідження Л.Н. Ожигової вказує на зв'язок емоційного вигорання із завищеною самооцінкою в акторів, а також зв'язок емоційного вигорання та середнього рівня самооцінки й особистісної тривожності серед педагогів [15, с. 262].

Розгляд наукової літератури дає змогу встановити, що вченими приділяється значна увага дослідженню самосвідомості матері, специфіці її прояву та трансформації протягом періоду материнства. Поряд із цим проблема особливостей самосвідомості матерів із емоційним вигоранням залишається не досить розкритою у наукових дослідженнях. Вигорання у вітчизняних дослідженнях більшою мірою вивчається у професійній сфері. Зокрема, у роботах В.В. Бойко, Н.Е. Водоп'янової, В.Е. Орел, Г.А. Робертс, а емоційне вигорання вивчається у роботах таких авторів, як: А.А. Рукавішніков, Н.Е. Водоп'янова, Г. Сельє, С. Maslach, А. Pines та ін. [4, с. 12; 7 , c. $62 ; 8$, c. $15 ; 16$, c. $33 ; 17$, c. $164 ; 20$, c. 65 ; 28, c. 101].

Концепція батьківського вигорання була висунута у США ще наприкінці XX ст. (Procaccini та Kiefaver, 1983), але, попри це, феномен батьківського вигорання залишається не досить дослідженим. Здебільшого вивчалось батьківське вигорання у ситуації хворих дітей (L. Norberg, 2007; Lindstr m та ін. 2010; Karadavut та Uneri, 2011; L. Norberg та ін., 2014). Меншою мірою сучасні наукові дослідження висвітлюють батьківське вигорання у батьків здорових дітей $[28$, с. $11 ; 33$, с. 105 ; 30, c. 20].

Вчені виокремлюють такі психологічні особливості матерів із високим рівнем емоційного вигорання, як: зниження особистих досягнень, деперсоналізація, емоційне виснаження, прагнення до перфекціонізму, 
прагнення відповідати соціальним нормам, автоматична поведінка, психосоматичні симптоми (S. Hubert та I. Aujoulat) [31, с. 1]; емоційне дистанціювання від своїх дітей, почуття некомпетентності у батьківській ролі (Mikolajczak); депресія та тривога (А. Lebert-Charron, G. Dorard, E. Boujut, J. Wendland); педантичність та відсутність емоційного контролю (S. LeVigouroux, C. Scola) [34, с. 20]; наявність дітей, старших за 18 місяців, та депресивний настрій, що не є генералізованим, а стосується саме батьківської ролі (А. Nunes Tuna, I. Roskam, M. Mikolajczak); страх бути «не досить гарною матір'ю» (D.W. Winnicott); психосоматичні симптоми, неспроможність до планування, сором, самотність, відчуття вини тощо (S. Hubert та I. Aujoulat); хронічна втома через постійну опіку дитини та невдоволеність ставленням близьких до себе (Г.Г. Філіппова) [5, с. 13]; емоційна відстороненість, напруженість у відносинах, тривожність та непослідовність, низька задоволеність відносинами з дитиною і ї̈ відторгнення [2, с. 5]; тривога і депресія [29, с. 25].

На індивідуальне Я впливає тривога, страх, почуття власної некомпетентності; реляційне Я страждає від емоційного дистанціювання з дітьми і, як наслідок, має почуття особистого неблагополуччя; колективне Я також характеризується низьким рівнем прояву, через втрату соціальних зв'язків та самотність. Отже, в результаті батьківського вигорання матері стикаються із проблемами самопрезентації в таких аспектах Я: індивідуальне Я, реляційне Я та колективне Я [26, с. 1; 28, с. 20].

Таким чином, виявлені такі особливості самосвідомості матерів із емоційним вигоранням, як: деперсоналізація (S. Hubert та I. Aujoulat), зниження самооцінки, надмірна самокритичність (Л.А. Базалева), проблеми самопрезентації в аспектах індивідуальне Я, реляційне Я та колективне Я. Відхилення від ідеального образу матері переживається як особистісна нездатність, неповноцінність, зрада своєї дитини та свого «внутрішнього образу матері» (Г.Г. Філіппова) [2, с. 5].

Методика та організація дослідження. у пілотажному дослідженні взяли участь 30 жінок віком від 24 до 78 із середньою та вищою професійною освітою, що перебувають у шлюбі та мають від 1 до 10 дітей. Відповідно до логіки та мети дослідження були використані такі методики, які спрямовані на діагностику рівня самоповаги, емоційного вигорання, самоставлення та дослідження ідентичності, а саме: Шкала самоповаги М. Розенберга (Rosenberg's Self-Esteem Scale, 1965) [32, с. 132]; Тест-опитувальник самовідношення (В.В. Столін, С.Р. Пантелеєв, 1988) [22, с. 130]; Методика діагностики рівня емоційного вигорання В.В. Бойко (1996)
[4, с. 130]; Тест «Хто Я?» (М. Кун та Т. МакПартленд, модифікація Т.В. Рум'янцевої) [23, с. 82]. Для математико-статистичного аналізу використовувся r-критерій Пірсона в пакеті IBM SPSS Statistics 26.

Виклад основного матеріалу. У результаті емпіричного збору даних за опитувальником «Хто Я?» було встановлено, що у більшості матерів переважає завищена самооцінка $(46,6 \%)$, адекватна самооцінка - 26,6\% досліджуваних, занижена - 3,3\%. Більшість матерів, що взяли участь у дослідженні, характеризуються емоційною полярністю (70\%), що свідчить про схильність розподіляти всі події навколишнього світу за принципом «чорно-білого» мислення. Така особистісна особливість, імовірно, свідчить про примітивність, дихотомічність мислення та є одним із можливих симптомів алекситимії. До врівноваженого типу було віднесено 16,6\% опитаних жінок, а у групу осіб, що мають сумніви, увійшли 6,6\% респондентів. Показник останньої групи може бути свідченням переживання кризи у житті, вказувати на нерішучість як рису характеру, схильність піддавати сумніву власні висновки, твердження тощо.

Найбільш представленими формами ідентичності у матерів $€$ рефлексивна $\left(x^{-}=53,5 \%\right)$, соціальна $\left(x^{-}=34,2 \%\right)$, діяльнісна ( $\left.x^{-}=8 \%\right)$, комунікативна $\left(x^{-}=3 \%\right)$, фізична $\left(x^{-}=1 \%\right)$, матеріальна та перспективна ( $\left.\mathrm{x}^{-}=1 \%\right)$, при цьому не було виявлено проблемної та ситуативної форм ідентичності. Припускаємо, що вираженість рефлексивної ідентичності серед матерів відображає значущість оцінки особистісних якостей, індивідуального стилю поведінки, персональних характеристик та емоційного ставлення до себе. Рівень вираженості соціальної ідентичності також підкреслює прояв «Соціального Я» крізь приналежність до сімейних, етнічних, політичних та релігійних груп тощо, засвідчує високий рівень усвідомленості цієї ідентичності. Показники вираженості діяльнісної, комунікативної, фізичної, матеріальної та перспективної ідентичності, ймовірно, свідчать про те, що ці аспекти особистості менш усвідомлені або витіснені матерями. Ймовірно, відсутність прояву проблемної та ситуативної ідентичності вказує на успішність функціонування у соціумі загалом.

Наступним етапом дослідження було виявлення зв'язків між самоповагою матерів як одного зі складників самоставлення (за Шкалою самоповаги М. Розенберга) та особистісними характеристиками жінок, а саме віком і стажем материнства. Отримані результати свідчать про відсутність зв'язку між самоповагою та віком ( $r=0,017)$; самоповагою і стажем материнства $(r=-0,146)$. Цей результат, можливо, пов'язаний і тим, що для сучасних матерів рівень самоповаги опосередковується не лише успішністю 
у сфері материнства та стажем материнства, а залежить від ширшого кола сфер, в яких жінка може реалізувати себе (розвиток кар'єри, особистісний ріст, сфера захоплень тощо). Вважаємо, що рівень самоповаги матерів може значною мірою варіюватись у різному віці і більшою мірою залежить від самоприйняття, здатності до адекватної та об'єктивної оцінки своїх переваг та недоліків, своїх життєвих перемог та невдач, відчуття власної компетентності й успішності [10, с. $6 ; 27$, с. 117$]$.

3 метою поглиблення та уточнення результатів дослідження було вирішено встановити ймовірність існування кореляційних зв'язків між емоційним вигоранням та самоставленням матерів (табл. 1).

Встановлено, що наявний додатній кореляційний зв'язок між самоприйняттям та переживанням обставин ( $r=0,389, p \leq 0,05)$, від'ємний кореляційний зв'язок існує між загальним показником самоставлення та загальним показником напруження ( $r=-0,381, p \leq 0,05)$, тривогою і депресією ( $r=-0,537, p \leq 0,01)$; між самоповагою та загальним показником напруження $(r=-0,409, p \leq 0,05)$, тривогою і депресією ( $r=-0,563, p \leq 0,01)$; між очікуваним ставленням інших та загальним показником напруження $(r=-0,479, p \leq 0,01)$, тривогою i депресією ( $r=-0,384, p \leq 0,05)$, загальним показником виснаження $(r=-0,489, p \leq 0,01)$, особистісною відстороненістю ( $r=-0527, p \leq 0,01)$, психосоматикою $(r=-0,534, p \leq 0,01)$; між самовпевненістю та тривогою і депресією ( $r=-0,369, p \leq 0,05)$; між ставленням інших та загальним показником напруження $(r=-0,405, p \leq 0,05)$, тривогою та депресією ( $r=-0,398, p \leq 0,05)$, особистісною відстороненістю ( $r=-0,361, p \leq 0,05)$; між самокерівництвом та загальним показником напруження $(r=-0,409, p \leq 0,05)$, незадоволеністю собою ( $r=-0,454, p \leq 0,05)$, тривогою та депресією ( $r=-0,372, p \leq 0,05)$, неадекватним реагуванням ( $r=-0,409, p \leq 0,01)$, психосоматикою $(r=-0,373, p \leq 0,05)$; між самоінтересом (як установкою на конкретні дії на адресу свого «Я») та психосоматикою ( $r=-0,386, p \leq 0,05)$; між саморозумінням та тривогою і депресією $(r=-0,403, p \leq 0,05)$, неадекватним реагуванням ( $r=-0,397, p \leq 0,05)$. Не було встановлено кореляційних зв'язків між «загнаністю у клітку», загальним показником резистенції, економією емоцій, редукцією професійних обов'язків, емоційним дефіцитом, емоційною відстороненістю та показниками самоставлення, а також між аутосимпатією та самоінтересом (глобальна шкала), самозвинуваченням та загальними показниками емоційного вигорання. Не було виявлено значущих кореляційних зв'язків між загальним показником напруження та самовпевненістю, самоприйняттям, самоінтересом (додаткова шкала) та саморозумінням; між переживанням обставин та загальним показником самоставлення, самоповагою, аутосимпатією, очікуваним ставленням інших, самовпевненістю, ставленням інших, самокерівництвом, самозвинуваченням, саморозумінням;

- загальний показник виснаження та загальний показник самоставлення, самоповага, аутосимпатія, самоінтерес, самовпевненість, ставлення інших, самоприйняття, самозвинувачення, самокерівництво, саморозуміння;

- особистісна відстороненість та загальний показник самоставлення, самоповага, аутосимпатія, самоінтерес, самовпевненість, самоприйнття, самозвинувачення, самокерівництво, саморозуміння. Йовірно, відсутність статистично значущих зв'язків за вказаними змінними може бути пов'язана 3 індивідуальними особливостями матерів. При цьому припускаємо, що негативне ставлення до себе підвищує загальний рівень напруженості та тривоги, позначається на шкалі очікування ставлення інших, що пояснює отриманий нами від'ємний кореляційний зв'язок. Виявлений від'ємний кореляційний зв'язок між загальним показником напруження та самоповагою, ймовірно, свідчить про те, що матері, які перебувають у стані виснаження та напруги, відчувають брак часу та психологічних ресурсів, приділяють менше уваги дітям, незадоволені результатами власної діяльності, що позначається на негативному ставленні до себе та низькому рівні самоповаги.

Значущі від'ємні кореляційні зв'язки між загальним показником напруження та очікуваним ставленням інших, ставленням інших як установкою на конкретну дію, скоріше за все, свідчать про те, що очікуване позитивне ставлення до себе інших та підтримка оточуючих людей $є$ ресурсом для матерів, який може допомогти запобігти виникненню емоційного вигорання. Цей висновок підтверджують результати досліджень С.В. Тайсаєвої та Т.Ю. Овсяннікової [14], а також О.О. Дорошева та Є.М. Кавлакан, вказуючи, що пошук соціальної підтримки, як і очікування позитивного ставлення інших, сприяють уникненню емоційного вигорання [9, с. 21]. Ймовірно, виявлений від'ємний кореляційний зв'язок між самокерівництвом та загальним показником напруження вказує на те, що особистісний контроль, прояв регуляційних можливостей «Я» у нових ситуаціях, активність та самостійність, високий рівень саморегуляції, а тому і самокерівництво є чинниками, що знижують імовірність розвитку емоційного вигорання. Встановлений негативний кореляційний зв'язок між самокерівництвом та загальним показником емоційного вигорання підтверджується у інших дослідженнях [14, с. 209; 18, с. 538].

Виявлений додатній кореляційний зв'язок між самоприйняттям та переживанням обставин, 


\section{ГАБІТУС}

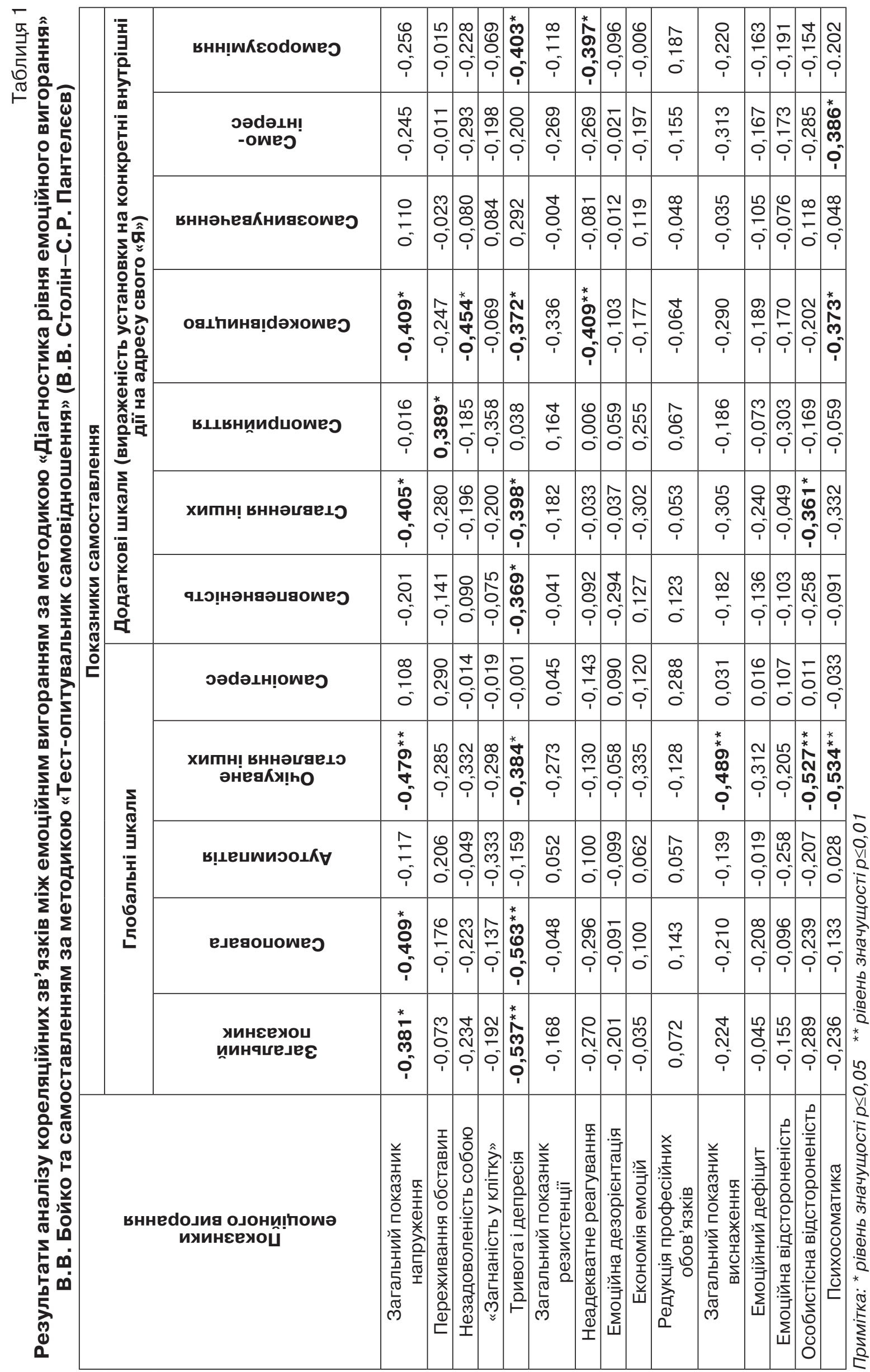


імовірно, пов'язаний із тим, що внаслідок переживання матерями стресових ситуацій та обставин, що викликають напруження, підвищується рівень готовності до виявлення самоприйняття (як установки на адресу свого «Я»), що відбувається у формі захисного механізму.

Протилежні результати були отримані у дослідженні Т.В. Макоти, проведеному серед військовослужбовців, де встановлено зв'язок самоприйняття із емоційною стабільністю та відсутністю схильності до емоційного вигорання. Тому розбіжності між результатами досліджень пов'язані із певними відмінностями механізмів виникнення та прояву емоційного вигорання матерів та військовослужбовців [11, с. 216].

Встановлений від'ємний кореляційний зв'язок між шкалами самокерівництво та незадоволеність собою, скоріше за все, свідчить про те, що особистість, яка схильна до самоконтролю, автономності, високого рівня саморегуляції, досягає вищих результатів у діяльності та вибудовуванні відносин 3 іншими членами сім'ї та своїми дітьми, а тому відчуває задоволеність собою. Можливо, матері 3 адекватною самооцінкою, впевненістю у собі, позитивним самоставленням і сильним «Я», мають більше особистісних ресурсів для протидії розвитку тривоги і депресивних станів, а тому демонструють низький рівень емоційного вигорання. Також було отримано від'ємні кореляційні зв'язки між самоставленням та симптомами вигорання і у іншому дослідженні [12, с. 97]. Ймовірно, для матерів із високим рівнем самоконтролю, самоорганізації, самоаналізу та розумінням себе властивий також високий рівень емоційного інтелекту, що, з одного боку, дозволяє регулювати власну поведінку, уникаючи неадекватних проявів, а з іншого боку, свідчить про високий рівень самокерівництва. Для матерів неадекватне реагування може бути пов'язане із розходженням між рівнем домагань і фактичними досягненнями, відчуттям самопожертви у ролі матері, негативною самооцінкою, а тому із низьким рівнем самокерівництва та саморозуміння [21, с. 190]. Виявлений від'ємний кореляційний зв'язок між загальним показником виснаження, особистісною відстороненістю та очікуваним ставленням інших, скоріше за все, свідчить про те, що для матерів із високим рівнем виснаження характерне переживання незадоволення собою, втоми, роздратування, відчуття втрати контролю над ситуацією, відчуття спустошення, зниження рівня особистісних ресурсів та незадоволення собою, емоційний дефіцит, що створює антигуманістичну установку та втрату інтересу до іншої людини або дитини і позначається на очікуваному ставленні оточуючих. Підтверджує отриманий результат і від'ємний зв'язок між особистіс- ною відстороненістю та ставленням інших (як вираженістю установки на конкретні внутрішні дії на адресу свого «Я»).

Статистично значущий кореляційний зв'язок між очікуваним ставленням інших та психосоматичними проявами, ймовірно, свідчить про те, що для матерів із високим рівнем виснаження, у яких погіршена здатність впоратись із навантаженнями, енергія емоцій перерозподіляється між іншими системами і знаходить прояв як у відхиленнях соматичних і психічних станів, так і у порушенні комунікацій, цинічному ставленні до партнера та дитини, а тому і у зниженні очікування позитивного ставлення до себе з їхнього боку.

Виявлені від'ємні кореляційні зв'язки між психосоматикою та самокерівництвом, самоінтересом, скоріше за все, пов'язані з тим, що матері, які не вважають себе основним джерелом власного розвитку, не відчувають власне «Я» як внутрішній стрижень, що координує та направляє активність, а тому негативні переживання, що не можуть бути висловлені дитині, виявляються на фізичному рівні. Жінка-мати, яка має високий рівень рефлексії та інтересу до себе, більшою мірою здатна усвідомлювати та регулювати власні емоційні стани, тому успішно долає кризові ситуації, уникаючи розвитку психосоматичних розладів.

Одним із аспектів вивчення самосвідомості матерів стало дослідження можливих детермінант переживання ними емоційного вигорання. Отже, було досліджено зв'язки між віком матерів, стажем материнства, кількістю дітей та фазами емоційного вигорання.

Були виявлені додатні кореляційні зв'язки між показниками емоційного вигорання та особистісними характеристиками, а саме: віком та психосоматикою $(r=0,383, p \leq 0,05)$; між стажем материнства та особистісною відстороненістю ( $r=0,401, \mathrm{p} \leq 0,05)$; психосоматикою $(r=0,512, p \leq 0,01)$. Не було встановлено кореляційних зв'язків між показниками емоційного вигорання та кількістю дітей у сім'ї, а також між віком та іншими показниками емоційного вигорання; стажем материнства та іншими показниками емоційного вигорання. Ймовірно, за винятком психосоматичних проявів як фізіологічного рівня прояву емоційного вигорання загалом, вік та кількість дітей не $€$ факторами, що опосередковують інтегральні показники фаз емоційного вигорання. Припускаємо, що емоційне вигорання значною мірою варіюється у матерів із різним стажем і не пов'язане прямо зі стажем материнства, за винятком встановленого статистично значущого додатного кореляційного зв'язку між стажем материнства та особистісною відстороненістю, що може бути пов'язане із тим, що любов матері до дитини, замкнутість простору діадної взаємодії може настільки поглинути 


\section{Результати аналізу кореляційних зв'язків між емоційним вигоранням за методикою “Діагностика рівня емоційного вигорання" В.В. Бойко та особистісними характеристиками осіб}

\begin{tabular}{|c|c|c|c|}
\hline \multirow{2}{*}{ Показники емоційного вигорання } & \multicolumn{3}{|c|}{ Особистісні характеристики } \\
\cline { 2 - 4 } & Вік & Стаж материнства & Кількість дітей \\
\hline Загальний показник напруження & $-0,027$ & 0,026 & $-0,047$ \\
\hline Переживання обставин & 0,241 & 0,192 & $-0,243$ \\
\hline Незадоволеність собою & $-0,081$ & $-0,031$ & 0,042 \\
\hline «Загнаність у клітку» & $-0,253$ & $-0,109$ & 0,168 \\
\hline Тривога і депресія & $-0,011$ & $-0,003$ & $-0,061$ \\
\hline Загальний показник резистенції & 0,1500 & 0,213 & 0,007 \\
\hline Неадекватне реагування & 0,058 & 0,122 & 0,279 \\
\hline Емоційна дезорієнтація & 0,028 & $-0,023$ & $-0,113$ \\
\hline Економія емоцій & 0,113 & 0,159 & $-0,170$ \\
\hline Редукція професійнихобов'язків & 0,160 & 0,250 & 0,036 \\
\hline Загальний показник виснаження & 0,172 & 0,296 & 0,093 \\
\hline Емоційний дефіцит & $-0,085$ & $-0,008$ & 0,145 \\
\hline Емоційна відстороненість & $-0,017$ & 0,052 & 0,008 \\
\hline Особистісна відстороненість & 0,275 & $\mathbf{0 , 4 0 1}$ & 0,044 \\
\hline Психосоматика & $\mathbf{0 , 3 8 3 ^ { * }}$ & $\mathbf{0 , 5 1 2 * *}$ & 0,104 \\
\hline
\end{tabular}

Примітка: * рівень значущості $\mathrm{p}=0,05$ ** рівень значущості $\mathrm{p}=0,01$

жінку, що спричинить відчуття втоми, дратівливості, байдужості стосовно дитини та близьких. Припускаємо, що на отриманий результат міг вплинути високий рівень представленості дихотомічного мислення у жінок, що заважає об'єктивізувати наявну реальність та власні судження, а це призводить до переоцінки значення негативних подій у реалізації материнства $[1$, с. 168]. Встановлені статистично значущі зв'язки між психосоматикою та стажем і віком матерів пов'язані із тим, що суттєву роль відіграють: підвищена емоційність і особливості генеративної функції (менструальний цикл, вагітність, лактація, клімакс). Психосоматичні розлади пов'язані із віком осіб, а особливо вплив цього фактору підвищується у старечому віці [19, с. 4].

Висновки. Дослідження проблеми самосвідомості матерів у процесі переживання ними емоційного вигорання дозволяє сформулювати низку висновків, а саме:

1) самосвідомість матерів являє собою складне утворення, що включає самопізнання, самореалізацію та самоставлення;

2) побудова образу себе як матері пов'язана із виконанням материнської ролі, присвоєнням позиції «Я-мати», усвідомленням свого нового соціального статусу;

3) одним із факторів, що зумовлює особливості самосвідомості матерів, виступає емоційне вигорання, котре порушує самопрезентацію жінки, адекватність її самооцінки, підвищує самокритичність, формує відчуття власної неповноцінності себе як особистості і т. ін.;
4) матерям властива емоційна полярність, найбільш виразно представлені рефлексивна та соціальна форми ідентичності. Зазначено, що характерною рисою сучасних матерів $€$ розширення кола сфер, в яких жінка може реалізувати себе, тому рівень самоповаги жінок-матерів не визначається лише успішністю материнства. Виявлено існування зв'язку між самоставленням та фазами напруження, резистенції й виснаження. Визначено, що опосередковують емоційне вигорання матерів підвищена емоційність, особливості генеративної функції жінок. Перспективу подальших досліджень вбачаємо у поглибленні та продовженні дослідження із розширенням вибірки досліджуваних, а також у вивченні ролі особистісної зрілості та перфекціонізму в процесі переживання емоційного вигорання матерями.

\section{ЛITEPATУРA:}

1. Базалева Л. Возможности исследования эмоционального выгорания у матерей в психологии личности. Вестник Адыгейского государственного университета. Серия «Педагогика и психология», 2010. № 1. C. 168-176.

2. Базалева Л. Личностные фракторы эмоционального «выгорания» матерей в отношениях с детьми : автореф. дисс. ... канд. психол. наук : 19.00.04. Краснодар, 2010. 26 с.

3. Бойко В. Психоэнергетика. Санкт-Петербург : Питер, 2008. 416 с.

4. Бойко В. Синдром «эмоционального выгорания» в профессиональном общении. Санкт-Петербург : Сударыня, 1999. 105 с. 
5. Валитова И. Особенности самосознания матери ребенка с ограниченными возможностями здоровья. Развитие личности, 2018. № 4. URL: https://cyberleninka.ru/article/n/osobennostisamosoznaniya-materi-rebenka-s-ogranichennymivozmozhnostyami-zdorovya.

6. Васягина Н., Рыбакова Е. Структурно-содержательный анализ самосознания матери. Образование и наука, 2007. № 2. С. 75-86.

7. Водопьянова Н. Психодиагностика стресса. Санкт-Петербург : Питер, 2009. 336 с.

8. Водопьянова Н., Старченкова Е. Синдром выгорания: диагностика и профилактика. СанктПетербург : Питер. 2005. 336 с.

9. Дорошева Е., Кавлакан Е. Психометрические свойства русскоязычной версии опросника «регуляция эмоций у родителей». Reflexio, 2019. № 12(2). C. 21-35.

10. Западнюк А. Особливості дисфункційних схем матерів із різним самоставленням. 2019. URL: https:// core.ac.uk/download/pdf/232853920.pdf

11. Макота Т. Емоційне вигорання як наслідок емоційної нестійкості особового складу підрозділів спеціального призначення. Вісник Національного університету оборони України, 2012. № 3. С. 216-220.

12. Метельська Н. Вплив емоційного вигорання на розвиток профресійної самосвідомості педагогічних працівників. Психологія і особистість, 2015. № 1. С. 97-108.

13. Овсянникова Т. Психологические условия предупреждения синдрома эмоционального выгорания у преподавателей высшей школы : автореф. дис. ... канд. психол. н. Нижний Новгород, 2008. 25 c.

14. Овсянникова Т., Тайсаева С. К вопросу о предупреждении синдрома выгорания у преподавателей. Личность, семья и общество: вопросы педагогики и психологии, 2014. № 47. С. 209-214.

15. Ожигова Л. Эмоциональное выгорание и самооценка личности у актеров и педагогов. Теория и практика общественного развития, 2015. № 16. C. 262-264. URL: https://cyberleninka.ru/article/n/ emotsionalnoe-vygoranie-i-samootsenka-lichnosti-uakterov-i-pedagogov.

16. Орел В. «Синдром психического выгорания» и стилевые особенности поведения и деятельности профессионала. Сибирский психологический журнал, 2006. № 23. С. 33-39.

17. Орел В., Рукавишников А. Исследование влияния фракторов рабочей среды на френомен психического выгорания в профессиях социальной сфреры. Социальная психология XXI век, 1999. Т. 2. C. 164-167.

18. Попова Т. Экспериментальное исследование эмоционального выгорания, самоотношения и самоактуализации практических психологов. Экспери- ментальная психология в России: традиции и перспективы, 2010. С. 538-542.

19. Психосоматические заболевания: Полный справочник. / Под ред. Елисеева Ю. Изд : ЭКСМО, 2003, 608 c.

20. Робертс Г. Профрилактика выгорания. Вопросы общей психиатрии, 1998. Вып. 1. С. 65-72.

21. Савенко Д. Структурна організація самосвідомості матері. Психологія: реальність і перспективи, 2016. Вип. 7. С. 190-193.

22. Столин В., Пантилеев С. Опросник самоотношения. Практикум по психодиагностике: Психодиагностические материалы. Москва, 1988. C. $123-130$.

23. Тест Куна М. Тест «Кто Я?» (М. Кун, Т. Макпартленд; модификация Т.В. Румянцевой). Психологическое консультирование: диагностика отношений в паре. Санкт-Петербург. 2006. С. 82-103.

24. Устинова Н. Внутриличностные детерминанты самосознания матери : авторефр. дис. ... канд. психол. наук. Екатеринбург, 2009. 22 с.

25. Чибисова М. Феномен материнства и его отражение в самосознании современной молодой женщины : дис. ... канд. психол. наук. Москва, 2003. 272 с.

26. Brewer M., Sedikides C. Individual self, relational self, collective self. Psychology Press, 2001. Pp. 1-3.

27. Dunford E., Granger C. Maternal Guilt and Shame: Relationship to Postnatal Depression and Attitudes towards Help-Seeking. 2017. URL: https://link. springer.com/article/10.1007/s10826-017-0690-z.

28. Hubert S., Aujoulat I. Parental burnout: When exhausted mothers open up. Frontiersin psychology, 2018. No. 9. 1021 p.

29. Lebert-Charron A., Dorard G., Boujut E., Wendland J. Maternal burnout syndrome: Contextual and psychological associated factors. Frontiersin psychology, 2018. No. 9. 885 p.

30. Mikolajczak M., Roskam I. Stress et dé fis de la parentalité: Thématiques contemporaines. De Boeck Supérieur, 2016. No. 30. 100 p.

31. Nunes Tuna A., Roskam I., Mikolajczak M. Le diagnostic différentiel: burnout parental, dépression, dépression post-partum. Comment faire la différence? Le Burnout Parental. Comprendre et Prendre en Charge, 2018. URL: http://hdl.handle.net/2078.1/thesis:8656/.

32. Robinson J., Shaver P. Measures of social psychological attitudes. Ann Arbor, MI: Survey Research Center, Institute for Social Research, 1973. Pp. 132-133.

33. Roskam I., Raes M., Mikolajczak M. Exhausted parents: development and preliminary validation of the parental burnout inventory. Frontiers in psychology, 2017. No. 8, p. 163.

34. Vigouroux S., Scola C. Differences in parental burnout: influence of demographic factors and personality of parents and children. Frontiers in psychology, 2018. No. 9. 887 p. 